\title{
Phenolic contents, antioxidant activity and colour density of Slovak Pinot Noir wines
}

\author{
Natália ČERYOVÁ ${ }^{1,2}$, Daniel BAJČAN ${ }^{1}$, Judita LIDIKOVÁ ${ }^{1}$, Marek ŠNIRC ${ }^{1}$, Pavol TREBICHALSKÝ ${ }^{1}$, \\ Janka BERESECKÁ ${ }^{3}$, Jarmila HORVÁTHOVÁ ${ }^{4}$,
}

Received January 14, 2021; accepted May 06, 2021. Delo je prispelo 14. januarja 2021, sprejeto 6. maja 2021

\begin{abstract}
Phenolic contents, antioxidant activity and colour density of Slovak Pinot Noir wines

Abstract: Recent studies show that wine contains more than thousand different compounds that could come from grapes, or could be formed in the process of winemaking and maturing. The most abundant compounds in wines are polyphenols, which affect sensory properties such as colour, taste and aroma, but also has antioxidant properties. The aim of this study was to determine total polyphenol and total anthocyanin contents, and to evaluate antioxidant effects and wine colour density of red wines 'Pinot Noir' produced in Slovakia. Thirteen analysed, bottled, quality dry 'Pinot Noir' wines with origin in various Slovak wine regions were purchased in retail network, to provide that analysed samples of wine would have the same properties as wines that are consumed by common consumers. The content of total polyphenols in analysed 'Pi-

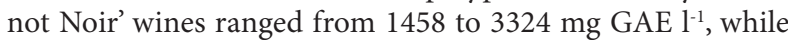
contents of total anthocyanins ranged from 43.6 to $279.6 \mathrm{mg}$ $\mathrm{l}^{-1}$. Antioxidant activities ranged from $80.2 \%$ to $85.3 \%$ inhibition of DPPH and wine colour density ranged from 0.679 to 1.495 . The highest total polyphenol content, total anthocyanin content, and wine colour density was determined in wines from the south Slovakia winegrowing region, while the highest antioxidant activity in wines from Nitra winegrowing region. Results did not show significant differences among studied parameters in wines from different winegrowing regions. Results showed that Slovakian 'Pinot Noir' wines have characteristics comparable with 'Pinot Noir' wines from other countries.
\end{abstract}

Key words: wine; polyphenols; antioxidant activity; anthocyanins; 'Pinot Noir'
Vsebnost fenolov, antioksidacijska aktivnost in obarvanost slovaških vin iz sorte Pinot Noir

Izvleček: Sedanje raziskave kažejo, da vsebujejo vina več kot tisoč različnih spojin, ki izvirajo iz grozdja ali pa se lahko tvorijo $\mathrm{v}$ procesu pridelave in zorenja vina. Najpogostejše spojine $\mathrm{v}$ vinu so polifenoli, ki vplivajo na senzorične lastnosti vina kot so barva, okus in aroma, imajo tudi antioksidativne lastnosti. Namen raziskave je bil določiti celokupno vsebnost polifenolov in antocianinov in ovrednostiti obarvanost rdečih vin, ki se pridelujejo na Slovaškem iz sorte Pinot Noir. Analizirano je bilo trinajst ustekleničenih kakovostnih suhih vin črnega pinoja, ki so izvirala iz različnih vinorodnih območij Slovaške, pridobljenih iz prodaje na drobno, da bi se zagotovili vzorci vina $z$ enakimi lastnostmi kot jih ima vino v splošni porabi. Vsebnost celokupnih polifenolov $\mathrm{v}$ analiziranih vzorcih črnega pinoja je bila v območju od 1458 do $3324 \mathrm{mg}$ $\mathrm{GAE}^{-1}$, medtem, ko je bila vsebnost celokupnih antocianinov v območju od 43,6 do 279,6 $\mathrm{mg} \mathrm{l}^{-1}$. Antioksidacijska aktivnost je bila v območju od 80,2 \% do 85,3 \% inhibicije DPPH, obarvanost vina pa je bila v območju od 0,679 do 1,495 . Največje vsebnosti celokupnih polifenolov in antocianinov in največja obarvanost so bile določene v vzorcih vina iz južne Slovaške, največja antioksidacijska aktivnost pa $\mathrm{v}$ vinih iz vinorodnih območij Nitre. Izsledki niso pokazali značilnih razlik v preučevanih parametrih vin iz različnih vinorodnih območij, pokazali pa so, da so lastnosti slovaškega črnega pinoja primerljivi s črnimi pinoji iz drugih dežel.

Ključne besede: vino; polifenoli; antioksidacijska aktivnost; antocianini; 'Pinot Noir'

1 Slovak University of Agriculture in Nitra, Faculty of Biotechnology and Food Sciences, Department of Chemistry, Tr. A. Hlinku 2, 94976 Nitra, Slovak Republic

2 Corresponding author, e-mail: xceryova@uniag.sk

3 Slovak University of Agriculture in Nitra, Faculty of European Studies and Regional Development, Department of Regional and Rural Development, Tr. A. Hlinku 2, 94976 Nitra, Slovak Republic

4 Slovak University of Agriculture in Nitra, Faculty of Economics and Management, Department of Languages, Tr. A. Hlinku 2, 94976 Nitra, Slovak Republic 


\section{INTRODUCTION}

The wine contains a number of polyphenolic substances that can affect its important sensory properties, such as colour, taste, bitterness and astringency (Ivanova-Petropulos et al., 2015). Phenolic substances are involved mainly in the colour changes of grapes, and play a key role in determining the quality of the wine. Antioxidant properties of phenolic compounds have positive impact on the wine stability. Their concentration in wine is affected by temperature and time of maceration, presence of $\mathrm{SO}_{2}, \mathrm{pH}$, and process of micro-oxygenation (Mulero et al., 2015). Main phenolic compounds in red wines are tannins, anthocyanidins, flavonols, flavan3-ols, and stilbenes (Moreno and Peinado, 2012).

In viniculture, polyphenolic compounds play a very important role, because they affect the character, quality, taste, and colour of red wines (Li et al., 2009). The main source of polyphenols in wines are grape berries. They are in skin, pulp, seeds, and grape juice (Jackson, 2008). The final composition of polyphenolic compound in wine depends mainly on their content in grapes, which depends on many factors, such as climatic conditions, extraction, as well as winemaking technologies, and chemical reactions during the aging of wine (Atanacković et al., 2012).

Colour is one of the most important properties of red wines. Main cause of the red colour of wine are anthocyanins and their derivatives, which are formed during the fermentation process. Colour of red wine is influenced by many factors, including type and content of anthocyanins, $\mathrm{pH}$, free $\mathrm{SO}_{2}$ content, and extent of polymerization and co-pigmentation (Versari et al., 2008). During the first two years of wine maturation, monomeric anthocyanins go through a wide series of reactions, in which new pigments, important for colour stability, are formed. Although anthocyanins are odourless and almost tasteless, they can interact with other aromatic substances, and thus affect the taste of wine. Anthocyanins are water soluble flavonoid pigments, which contribute to the red, violet, or blue colour of the grapes, depending on the $\mathrm{pH}$ (He et al., 2012). Monomeric forms of anthocyanins are responsible for the red colour of young wines, and contribute to the development of red polymer pigments during the wine maturation (Versari et al., 2008). Main monomeric anthocyanins of red wines are 3-O-monoglucosides, which include delphinidin-3-O-glucoside, cyanidin-3-O-glucoside, petunidin-3-O-glucoside, peonidin-3-O-glucoside, and malvidin-3-O-glucoside (Jackson, 2008).

The antioxidant activity of anthocyanins is considered to be one of their most important physiological functions (Yang et al., 2009). Intake of anthocyanins has been linked to a number of human health benefits. They have strong antioxidant properties, and act as protective agents against many chronic diseases (Welch et al., 2008)

'Pinot Noir' is intended mainly for the production of quality varietal wines in the category of the late harvest to grape selection. It has a genetically lower content of anthocyanins. The usual alcohol content in these wines is about 13 vol. \%. The wines are lighter brick colour and their aroma is distinctly fruity reminiscent of cherries, plums, and forest fruits. Wines made from this variety are usually extractive with a pleasant taste of tannins and are suitable for archiving (Pavloušek, 2007). In ordinary vintages, it provides soft, velvety, alcoholic, full-bodied wines with a delicious almond bouquet. They reach their peak at the bottle maturity that, according to the year and quality, sometimes appears only after several years (Malík et al., 2005). According to the Vineyard Register of the Slovak Republic (2020), the total area of bearing vineyards as of 31.7.2020 was 11090 ha. Red grapevine varieties represent 3226 ha, ,Pinot Noir represents 223 ha. In the last decade, there has been a decrease of the total vineyard area by $23.2 \%$. According to OIV (2020), wine production in Slovakia in 2020 was cca $300000 \mathrm{hl}$, with Pinot Noir representing less than $1 \%$ of it.

The aim of this study was to determine and evaluate properties and their mutual correlations in Slovak wines Pinot Noir, and to compare them with other Slovak red wines.

\section{MATERIALS AND METHODS}

\subsection{SAMPLES}

Analysed, bottled, quality dry Pinot Noir (PN) wines and their characteristics are mentioned in Table 1. Wine samples with origin in various Slovak winegrowing regions (WR) were purchased in retail network, to provide that analysed samples of wine would have the same properties as wines that are consumed by common consumers.

\subsection{CHEMICALS AND INSTRUMENTS}

The chemicals used for all analysis were: Folin-Ciocalteau reagent, monohydrate of gallic acid p. a., anhydrous sodium carbonate p. a., citric acid p. a., disodium hydrogenphosphate dodecahydrate, $35 \%$ hydrochloric acid p. a., ethanol p. a., methanol p. a., 1,1-diphenyl1-picrylhydrazyl (DPPH) radical p. a., Trolox (pure). 
Table 1: Characteristics of analysed wines

\begin{tabular}{lllll}
\hline Sample & Producer & Winegrowing region & Quality & Vintage \\
\hline PN-LC1 & Karpatská Perla, Šenkvice & Little Carpathian & Grape selection 2011 \\
PN-LC2 & Mrva a Stanko, s. r. o., Trnava & Little Carpathian & Grape selection & 2012 \\
PN-LC3 & VPS, s. r. o., Pezinok & Little Carpathian & Grape selection 2013 \\
PN-LC4 & Lacko \& Majtán, Malacky & Little Carpathian & Quality & 2012 \\
PN-SS1 & Villa Víno Rača, a. s., Bratislava & South Slovak & Late harvest & 2013 \\
PN-SS2 & Víno Matyšḱk, s. r. o., Pezinok & South Slovak & Grape selection 2012 \\
PN-SS3 & Vinárske závody Topolčianky, s. r. o. & South Slovak & Quality & 2013 \\
PN-SS4 & Vinárske závody Topolčianky, s. r. o. & South Slovak & Late harvest & 2013 \\
PN-SS5 & Víno Nitra / Ch. Modra, Trnava & South Slovak & Grape selection & 2012 \\
PN-N1 & Muráni-Víno Čajkov, s. r. o., Čajkov & Nitra & Cabinet & 2010 \\
PN-N2 & Agropest, s.r. o., Velký Cetín & Nitra & Grape selection & 2012 \\
PN-N3 & Pivnica Radošina, s.r.o. Trnava & Nitra & Grape selection 2012 \\
PN-N4 & PD Mojmírovce & Nitra & Grape selection & 2012 \\
\hline
\end{tabular}

PN - Pinot Noir, LC - Little Carpathian winegrowing region, SS - South Slovakia winegrowing region, N - Nitra winegrowing region

All analysed parameters - total polyphenol content, total anthocyanin content, antioxidant activity and wine colour density in wines were analysed by UV/ VIS spectrophotometry (spectrophotometer Shimadzu UV/VIS - 1240, Shimadzu, Japan).

\subsection{WINE ANALYSIS}

\subsubsection{Determination of total polyphenol content}

Total polyphenol content (TPC) was assessed by the modified method of Singleton \& Rossi (1965) using of $20 \%$ solution of $\mathrm{NA}_{2} \mathrm{CO}_{3}$, Folin-Ciocalteau reagent and distilled water. $1 \mathrm{ml}$ of wine sample was pipetted into $50 \mathrm{ml}$ volumetric flask and diluted with $25 \mathrm{ml}$ of distilled water. Then, $2.5 \mathrm{ml}$ Folin-Ciocalteau reagent was added to dilute the mixture, and after 3 minutes, $1.5 \mathrm{ml}$ of $20 \%$ solution of $\mathrm{Na}_{2} \mathrm{CO}_{3}$ was added. Then, the sample was filled with distilled water to volume $50 \mathrm{ml}$, and after mixing, left at the laboratory temperature for 2 hours. The blank and calibration solutions of gallic acid were prepared by the same procedure. The absorbance of samples solutions was measured against blank solution at $765 \mathrm{~nm}$. The content of total polyphenols in wines was calculated as the amount of gallic acid equivalent (GAE) in mg per 1 litre of wine $\left(\mathrm{mg} \mathrm{GAE} . \mathrm{l}^{-1}\right)$.

\subsubsection{Determination of antioxidant activity}

Antioxidant activity (AA) was assessed by the method of Brand-Williams et al. (1995) using of DPPH
(2, 2-diphenyl-1-picrylhydrazyl) radical. Exactly, $3.9 \mathrm{ml}$ of DPPH solution was pipetted into cuvette. The absorbance of DPPH solution was measured at $515.6 \mathrm{~nm}$. Then, $0.1 \mathrm{ml}$ of wine sample was added, stirred, and left for 10 minutes. After 10 minutes, absorbance at 515.6 $\mathrm{nm}$ was measured, and antioxidant activity was expressed as \% inhibition of DPPH, and also as Trolox equivalent calculated from the calibration curve $\left(\mathrm{TE}^{-1}\right)$

\subsubsection{Determination of total anthocyanin content}

Total anthocyanin content (TAC) was assessed by the modified $\mathrm{pH}$ differential method of Lapornik et al. (2005), based on the transformation of all anthocyanins to red coloured flavylium cation by reduction of the $\mathrm{pH}$ of wine samples with $\mathrm{HCl}$ solution to values $0.5-0.8$. The total anthocyanin content was calculated from the difference of absorbance values of both solutions (diluted original and a sample of wine acidified with $\mathrm{HCl}$ ) and expressed as the amount of malvidin-3-monoglucoside in $\mathrm{mg} \mathrm{l}^{-1}$ of wine.

\subsubsection{Determination of wine colour density}

Wine colour density (WCD) was measured by the method of Sudrand (1958) as the sum of the absorbance at $420 \mathrm{~nm}$ and $520 \mathrm{~nm}$. The absorbance of the wine samples was measured in $0.2 \mathrm{~cm}$ path length glass cells. WCD was also expressed in the absorbance unit (AU) 
considering dilution factor $(\mathrm{R}=5)$, for obtaining better comparison with other authors.

All chemical analyses were performed as four parallels. Results were expressed by average \pm standard deviation.

\subsection{STATISTICAL ANALYSIS}

MS Excel 2016 and XLSTAT were used to perform statistical analysis. To obtain statistically significant information about the differences between the tested samples, nonparametric Kruskal-Wallis test was conducted (Addinsoft, 2014).

\section{RESULTS AND DISCUSSION}

All studied parameters - total polyphenols content (TPC), total anthocyanins content (TAC), antioxidant activity (AA) and wine colour density (WCD) of the Slovak Pinot Noir wines are described in Table 2.

Total polyphenols content (TPC) in analysed wines ranged from 1458 to $3324 \mathrm{mg} \mathrm{GAE}^{-1}$, reaching an average TPC 2334 mg GAE.1 ${ }^{-1}$. TPC in Slovak Pinot
Noir wine was about the same as TPC in Argentinian Pinot Noir wines (2319 $\mathrm{mg} \mathrm{GAE}^{-1}$ ), higher than TPC in Croatian (1825 $\mathrm{mg} \mathrm{GAE}^{-1}$ ), Italian (2029 mg GAE $\left.\mathrm{l}^{-1}\right)$, French (2062 $\mathrm{mg} \mathrm{GAE}^{-1}$ ) and Chilean Pinot Noir wines (1759 $\mathrm{mg} \mathrm{GAE}^{-1}$ ), but lower than TPC in Czech (8714 $\mathrm{mg} \mathrm{GAE}^{-1}$ ) and French Pinot Noir wines (3545 mg GAE. ${ }^{-1}$ ) (Landrault et al., 2001; Mlček et al., 2019; Šeruga et al., 2011; Van Leeuw et al., 2014). Previous studies of Slovak red wines showed about the same TPC in Blaufränkisch wines - 2003 mg GAE.1 ${ }^{-1}$, Saint Laurent wines - $2297 \mathrm{mg} \mathrm{GAE}^{-11}$, Cabernet Sauvignon wines - $2424 \mathrm{mg} \mathrm{GAE}^{-1}$, and higher TPC in Slovak Alibernet wines - 3057 mg GAE ${ }^{-1}$ (Bajčan et al., 2012; Bajčan et al., 2015; Bajčan et al., 2016).

According to the average TPC, wines from SSWR reached the highest content (2543 $\left.\mathrm{mg} \mathrm{GAE}^{-1}\right)$, followed by wines from LCWR (2418 $\mathrm{mg} \mathrm{GAE}^{-1}$ ) and wines from NWR (1990 $\mathrm{mg} \mathrm{GAE}^{-1}$ ). However, the results did not show significant differences in TPC among Pinot Noir wines from different vineyard areas in Slovakia, as shown in Figure 1.

Total anthocyanins content (TAC) in analysed wines ranged from 43.6 to $279.2 \mathrm{mg} \mathrm{l}^{-1}$, reaching an average TAC $153.3 \mathrm{mg} \mathrm{l}^{-1}$. TAC in Slovak Pinot Noir wines was higher than TAC in Uruguayan Pinot Noir wines

Table 2: Total polyphenols content, total anthocyanins content, antioxidant activity and wine colour density in analysed Pinot Noir wines from Slovakia

\begin{tabular}{|c|c|c|c|c|c|c|}
\hline Sample & $\begin{array}{l}\text { TPC } \\
\left(\mathrm{mg} \mathrm{GAE} \mathrm{l}^{-1}\right)\end{array}$ & $\begin{array}{l}\text { TAC } \\
\left(\mathrm{mg} \mathrm{l}^{-1}\right)\end{array}$ & $\begin{array}{l}\mathrm{AA} \\
(\%)\end{array}$ & $\begin{array}{l}\text { AA } \\
\left(\mathrm{mmol} \mathrm{TE} \mathrm{l}^{-1}\right)\end{array}$ & $\mathrm{WCD}_{0.2}$ & $\begin{array}{l}\mathrm{WCD}_{1.0} \\
(\mathrm{AU})\end{array}$ \\
\hline PN-LC1 & $3138 \pm 52$ & $128.5 \pm 1.4$ & $81.9 \pm 0.3$ & $1.015 \pm 0.004$ & $0.956 \pm 0.011$ & $4.78 \pm 0.055$ \\
\hline PN-LC2 & $3039 \pm 26$ & $167.4 \pm 1.4$ & $80.5 \pm 0.5$ & $0.992 \pm 0.006$ & $1.049 \pm 0.008$ & $5.245 \pm 0.04$ \\
\hline PN-LC3 & $2035 \pm 26$ & $229.6 \pm 1.8$ & $83.9 \pm 0.5$ & $1.050 \pm 0.006$ & $0.771 \pm 0.015$ & $3.855 \pm 0.075$ \\
\hline PN-LC4 & $1458 \pm 25$ & $82.5 \pm 1.2$ & $84.5 \pm 0.4$ & $1.061 \pm 0.006$ & $0.918 \pm 0.014$ & $4.59 \pm 0.07$ \\
\hline Average LCWR & $2418 \pm 816^{\mathrm{a}}$ & $152 \pm 71.4^{\mathrm{a}}$ & $82.7 \pm 1.9^{\mathrm{a}}$ & $1.030 \pm 0.034^{\mathrm{a}}$ & $0.924 \pm 0.135^{\mathrm{a}}$ & $4.618 \pm 0.675^{a}$ \\
\hline PN-SS1 & $2604 \pm 13$ & $271.3 \pm 9.8$ & $80.7 \pm 0.5$ & $0.995 \pm 0.006$ & $1.495 \pm 0.021$ & $7.475 \pm 0.105$ \\
\hline PN-SS2 & $2690 \pm 24$ & $69.8 \pm 1.4$ & $85.3 \pm 0.4$ & $1.074 \pm 0.005$ & $0.679 \pm 0.006$ & $3.395 \pm 0.03$ \\
\hline PN-SS3 & $1777 \pm 24$ & $279.2 \pm 1.4$ & $83.8 \pm 0.3$ & $1.048 \pm 0.004$ & $0.959 \pm 0.008$ & $4.795 \pm 0.04$ \\
\hline PN-SS4 & $3324 \pm 26$ & $159.4 \pm 2.1$ & $81.0 \pm 0.4$ & $1.000 \pm 0.005$ & $1.113 \pm 0.016$ & $5.565 \pm 0.08$ \\
\hline PN-SS5 & $2318 \pm 25$ & $101.5 \pm 1.6$ & $82.7 \pm 0.4$ & $1.029 \pm 0.006$ & $1.045 \pm 0.009$ & $5.225 \pm 0.045$ \\
\hline Average SSWR & $2543 \pm 751^{\mathrm{a}}$ & $176.2 \pm 101.7^{\mathrm{a}}$ & $82.7 \pm 2.2^{\mathrm{a}}$ & $1.029 \pm 0.036^{\mathrm{a}}$ & $1.058 \pm 0.396^{\mathrm{a}}$ & $5.291 \pm 1.98^{\mathrm{a}}$ \\
\hline PN-N1 & $1995 \pm 25$ & $43.6 \pm 2.1$ & $84.3 \pm 0.6$ & $1.057 \pm 0.007$ & $0.832 \pm 0.007$ & $4.16 \pm 0.035$ \\
\hline $\mathrm{PN}-\mathrm{N} 2$ & $1943 \pm 12$ & $87.6 \pm 2.8$ & $80.2 \pm 0.5$ & $0.987 \pm 0.006$ & $1.156 \pm 0.016$ & $5.78 \pm 0.08$ \\
\hline PN-N3 & $1895 \pm 24$ & $199.5 \pm 1.4$ & $84.1 \pm 0.4$ & $1.053 \pm 0.005$ & $0.779 \pm 0.01$ & $3.895 \pm 0.05$ \\
\hline PN-N4 & $2125 \pm 25$ & $173.6 \pm 2.1$ & $83.6 \pm 0.6$ & $1.042 \pm 0.007$ & $0.923 \pm 0.015$ & $4.615 \pm 0.075$ \\
\hline Average NWR & $1990 \pm 112^{\mathrm{a}}$ & $126.1 \pm 75 . \mathrm{Z}^{\mathrm{a}}$ & $83.1 \pm 2.0^{\mathrm{a}}$ & $1.035 \pm 0.034^{\mathrm{a}}$ & $0.923 \pm 0.183^{\mathrm{a}}$ & $4.613 \pm 0.915^{\mathrm{a}}$ \\
\hline Total average & $2334 \pm 577$ & $153.3 \pm 76.4$ & $82.8 \pm 1.7$ & $1.031 \pm 0.030$ & $0.975 \pm 0.210$ & $4.875 \pm 1.05$ \\
\hline
\end{tabular}

Different letters indicate significant differences $(p<0.05)$ among different winegrowing regions. 
(78.1 $\mathrm{mg} \mathrm{l}^{-1}$ ), and lower than TAC in Australian Pinot Noir wines (190 $\mathrm{mg} \mathrm{l}^{-1}, 232 \mathrm{mg} \mathrm{l}^{-1}$ ) (Carew et al., 2013; Piccardo et al., 2019; Song et al., 2014).

Previous studies of Slovak red wines showed higher TAC in Blaufränkisch wines - $266.1 \mathrm{mg} \mathrm{l}^{-1}$, Saint Laurent wines - $264.0 \mathrm{mg} \mathrm{l}^{-1}$, Cabernet Sauvignon wines $220.6 \mathrm{mg} \mathrm{l}^{-1}$, and Alibernet wines - $403.0 \mathrm{mg} \mathrm{l}^{-1}$. (Bajčan et al., 2012; Bajčan et al., 2015; Bajčan et al., 2016).

According to the average TAC, wines from SSWR reached the highest content $\left(176.2 \mathrm{mg} \mathrm{l}^{-1}\right)$, followed by wines from LCWR (152 $\left.\mathrm{mg} \mathrm{l}^{-1}\right)$ and wines from NWR $\left(126 \mathrm{mg} \mathrm{l}^{-1}\right)$. However, the results did not show significant differences in TAC among Pinot Noir wines from different vineyard areas in Slovakia, as shown in Figure 1.

Antioxidant activity (AA) in analysed wines ranged

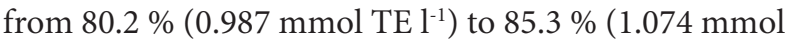
$\left.\mathrm{TE}^{-1}\right)$, reaching an average AA $82.8 \%$ (1.031 mmol TE $1^{-1}$.) AA in Slovak Pinot Noir wines was higher than AA in South American Pinot Noir wines (47.93 - 66.70 \%.), but lower than AA in Croatian Pinot Noir wines (4.3 mmol TE 1'-1) (Granato et al., 2011; Šeruga et al., 2011). Previous studies of Slovak red wines showed about the same AA in Blaufränkisch wines - $83.8 \%$, Saint Laurent wines - 81.2 \%, Cabernet Sauvignon wines - 78.8 $\%$, and lower average AA in Slovak Alibernet wines -
74.5 \% (Bajčan et al., 2012; Bajčan et al., 2015; Bajčan et al., 2016).

According to the average AA, wines from NWR reached the highest content ( $83.1 \%)$, followed by wines from LCWR $(82.7 \%)$ and wines from SSWR $(82.7 \%)$. However, the results did not show significant differences in TAC among Pinot Noir wines from different vineyard areas in Slovakia, as shown in Figure 1.

Wine colour density (WCD) in analysed wines ranged from 0.679 (3.395 $\mathrm{AU}$ ) to 1.459 (7.475 $\mathrm{AU})$, reaching an average WCD 0.975 (4.875 AU). Song et al., (2014) reported about the same average WCD in Australian Pinot Noir wines (3.61 - 8.47 AU). WCD in Slovak Pinot Noir wines was higher than WCD in Australian Pinot Noir wines (2.4 - 3.7 AU) (Carew et al., 2013). Previous studies of Slovak red wines showed higher WCD in Cabernet Sauvignon wines - 1.399 and Alibernet wines - 2.317 (Bajčan et al., 2015; Bajčan et al., 2016).

According to the average WCD, wines from SSWR reached the highest content (1.058), followed by wines from LCWR (0.924) and wines from NWR (0.923). However, the results did not show significant differences in WCD among Pinot Noir wines from different vineyard areas in Slovakia, as shown in Figure 1.

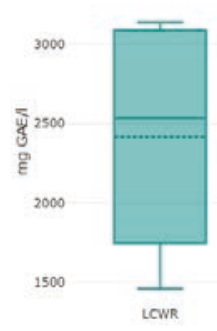

TPC

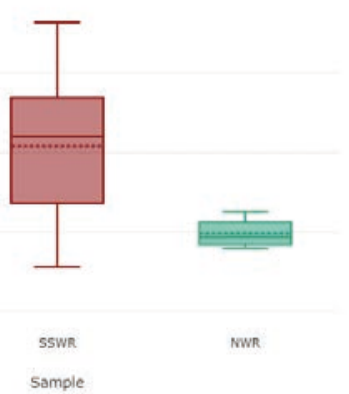

AA

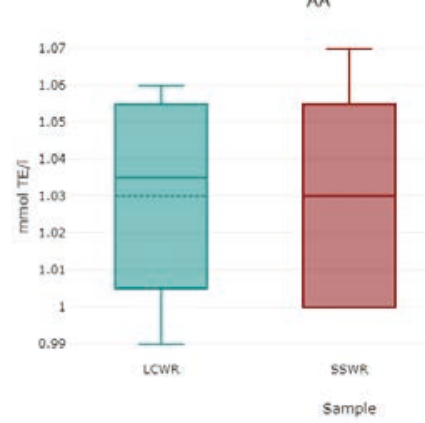

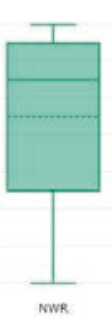
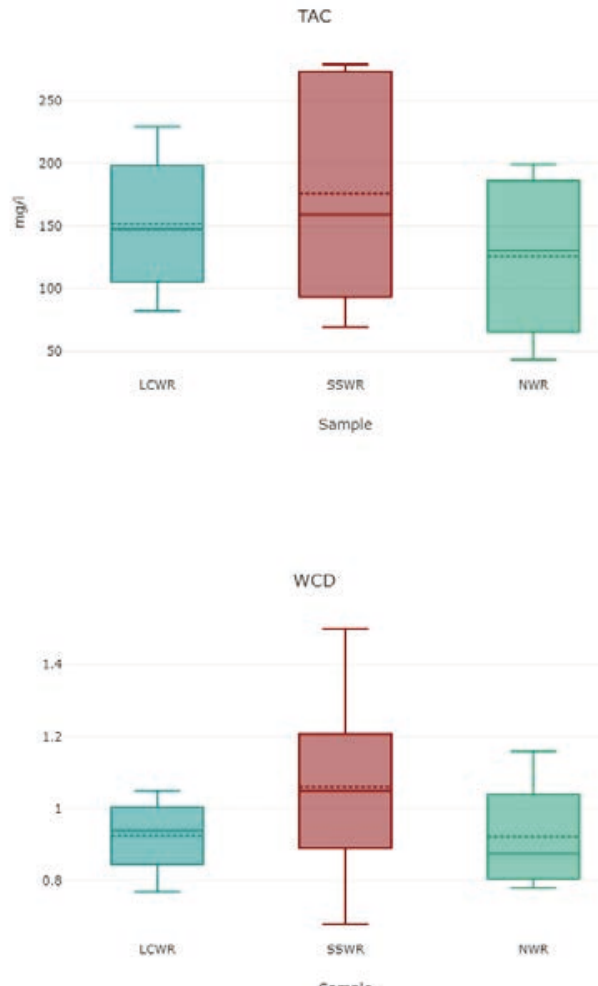

WCD
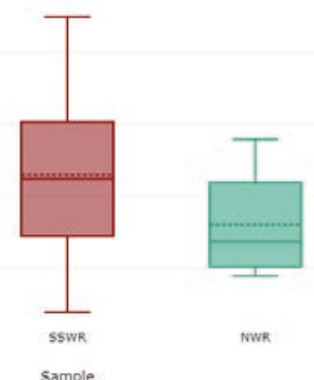

Figure 1: Differences among individual properties of wines from different winegrowing regions 
In order to examine the mutual relations among analysed parameters, the linear regressions were made. Results are shown in Figure 2. The statistical evaluation of the obtained results confirmed strong negative linear correlation between AA and WCD $(r=-0.825)$, which is in accordance with previous reports by Bajčan et al. (2016) for Slovak Cabernet Sauvignon wines and for Slovak Alibernet wines (Bajčan et al., 2015). Furthermore, there were not confirmed correlations between TPC and TAC $(r=0.01)$, between TPC and AA $(r=$ $-0.052)$, between TPC and WCD $(r=0.277)$, between TAC and AA $(r=-0.171)$, and between TAC and WCD $(r=0.038)$. Bajčan et al. (2015) and Bajčan et al. (2016) reported moderate positive correlations between TPC and TAC $(\mathrm{r}=0.542)$, TAC and WCD $(\mathrm{r}=0.600)$, and TPC and WCD $(r=0.697)$ in Slovak Cabernet Sauvignon wines and moderate positive correlation between TPC and TAC $(r=0.447)$, TAC and WCD $(r=0.660)$, moderate negative correlation between TAC and AA $(\mathrm{r}=-0.532)$, and strong positive correlation between WCD and TPC $(r=0.887)$, and strong negative correlation between TPC and AA $(r=-0.917)$ in Slovak Alibernet wines. Based on our results, it can be stated that there are no strong correlations between the individual monitored properties of wines, except for AA and WCD. These correlations are unusual and in disagreement with other authors. Granato et al. (2011) reported moderate positive correlation between TPC and AA $(r=0.59)$ in Australian Pinot Noir wines. Šeruga et al. (2011) reported strong positive correlation between TPC and AA in Croatian Pinot Noir wines $(r=0.9885)$.

\section{CONCLUSIONS}

Total phenolic contents, total anthocyanin contents, antioxidant activities and wine colour densities of Pinot Noir wines from three vineyard regions of Slovakia was determined in this study. Studied Pinot Noir wines showed high antioxidant activity, content of polyphenols and anthocyanins, the substances that contribute to the various health benefits.

The highest total polyphenol content, total anthocyanin content, and wine colour density was determined in wines from South Slovakia winegrowing region, while the highest antioxidant activity in wines from Nitra winegrowing region. At the end, Slovak Pinot Noir wines showed lower wine colour density in comparison to other Slovak wines. Results did not show significant differences among studied parameters in wines from different winegrowing regions. Based on statistical evaluation, strong negative correlation between antioxidant activity and wine colour density was determined.

\section{ACKNOWLEDGMENTS}

Work was supported by the Slovak Science Foundation VEGA (Grant no. 1/0114/18).

This publication was supported by the Operational program Integrated Infrastructure within the project: Demand- driven research for the sustainable and innovative food, Drive4SIFood 313011V336, cofinanced by the European Regional Development Fund.

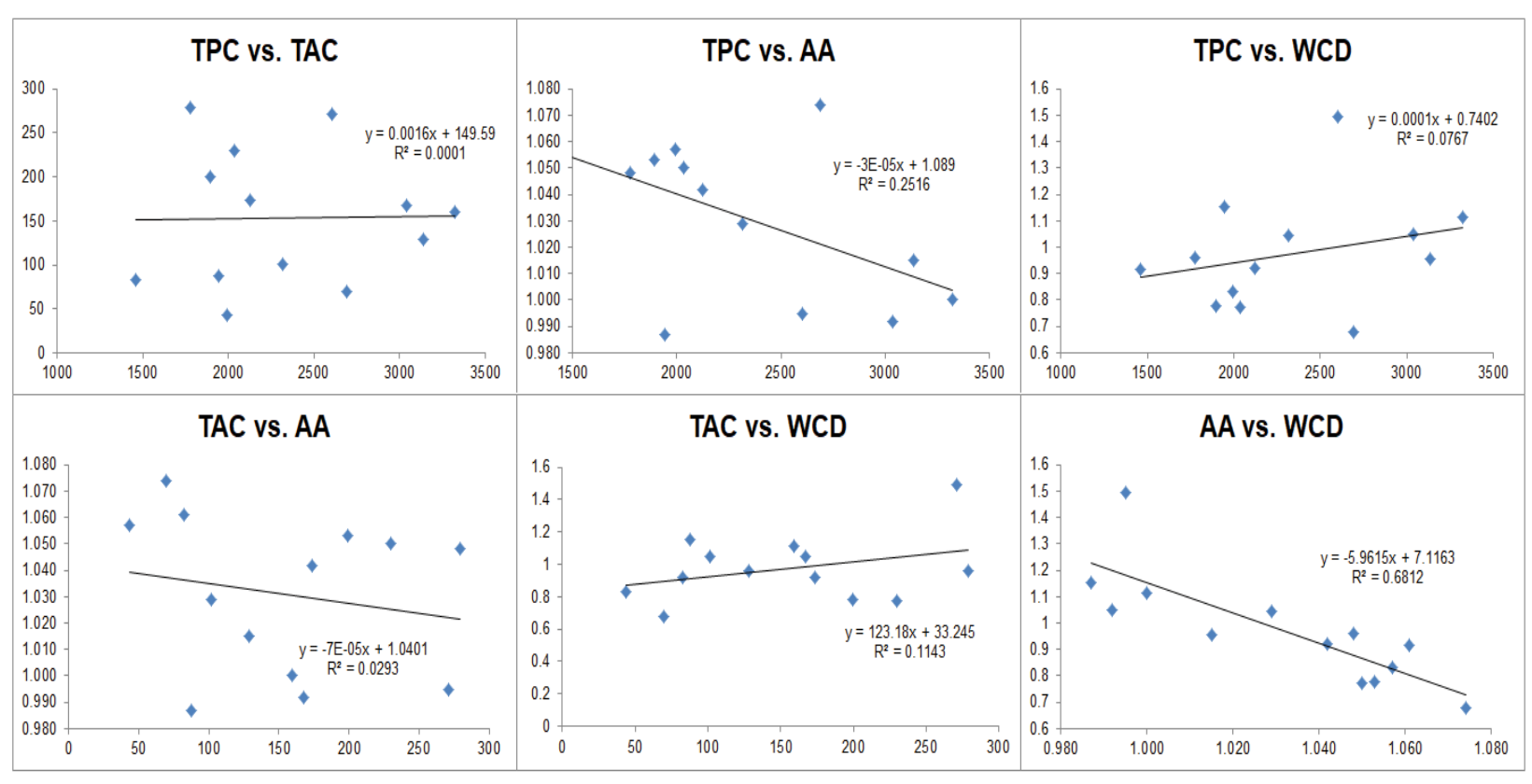

Figure 2: Correlations among analysed parameters 


\section{REFERENCES}

Addinsoft. (2014). XLSTAT, Analyse de données et statistique avec MS Excel. Addinsoft, NY, USA.

Atanacković, M., Petrović, A., Jović, S., Gojković-Bukarica, L., Bursać, M., Cvejić, J. (2012). Influence of winemaking techniques on the resveratrol content, total phenolic content and antioxidant potential of red wines. Food Chemistry, 131(2), 513-518. https://doi.org/10.1016/j.foodchem.2011.09.015

Bajčan, D., Čéryová, S., Tomáš, J. (2012). Antioxidant properties of the bestselling Slovak red wines. Journal of Microbiology, Biotechnology and Food Sciences, 1(4), 455-465. https://doi.org/10.15414/jmbfs.2015.4.special3.5-8

Bajčan, D., Šimanský, V., Tóth, T., Árvay, J. (2015). Colour, Phenolic content and antioxidant activity of the Slovak Alibernet red wine samples. Journal of Microbiology, Biotechnology and Food Sciences, 4(3), 5-8. https://doi. org/10.15414/jmbfs.2015.4.special3.5-8

Bajčan, D., Vollmannová, A., Šimanský, V., Bystrická, J., Trebichalský, P., Árvay, J. Á. J., Czako, P. (2016). Antioxidant activity, phenolic content and colour of the Slovak cabernet sauvignon wines. Potravinarstvo Slovak Journal of Food Sciences, 10(1), 89-94. https://doi.org/10.5219/534

Brand-Williams, W., Cuvelier, M. E., Berset, C. L. W. T. (1995). Use of a free radical method to evaluate antioxidant activity. LWT-Food Science and Technology, 28(1), 25-30. https:// doi.org/10.1016/s0023-6438(95)80008-5

Carew, A. L., Smith, P., Close, D. C., Curtin, C., Dambergs, R. G. (2013). Yeast Effects on Pinot noir Wine Phenolics, Color, and Tannin Composition. Journal of Agricultural and Food Chemistry, 61(41), 9892-9898. doi:10.1021/jf4018806

Granato, D., Katayama, F. C. U., de Castro, I. A. (2011). Phenolic composition of South American red wines classified according to their antioxidant activity, retail price and sensory quality. Food Chemistry, 129(2), 366-373. doi:10.1016/j.foodchem.2011.04.085

He, F., Liang, N. N., Mu, L., Pan, Q. H., Wang, J., Reeves, M. J., Duan, C. Q. (2012). Anthocyanins and their variation in red wines I. Monomeric anthocyanins and their color expression. Molecules, 17(2), 1571-1601. https://doi. org/10.3390/molecules17021571

Ivanova-Petropulos, V., Hermosín-Gutiérrez, I., Boros, B., Stefova, M., Stafilov, T., Vojnoski, B., Kilár, F. (2015). Phenolic compounds and antioxidant activity of Macedonian red wines. Journal of Food Composition and Analysis, 41, 1-14. https://doi.org/10.1016/j.jfca.2015.01.002

Jackson, R. S. (2008). Wine science: principles and applications. Academic press. https://doi.org/10.1006/abio.1995.1141

Landrault, N., Poucheret, P., Ravel, P., Gasc, F., Cros, G., Teissedre, P.-L. (2001). Antioxidant Capacities and Phenolics Levels of French Wines from Different Varieties and Vintages. Journal of Agricultural and Food Chemistry, 49(7), 3341-3348. doi:10.1021/jf010128f

Lapornik, B., Prošek, M., Wondra, A. G. (2005). Comparison of extracts prepared from plant by-products using different solvents and extraction time. Journal of Food Engineering, 71(2), 214-222. https://doi.org/10.1016/j.jfoodeng.2004.10.036
Li, H., Wang, X., Li, Y., Li, P., Wang, H. (2009). Polyphenolic compounds and antioxidant properties of selected China wines. Food Chemistry, 112(2), 454-460. https://doi. org/10.1016/j.foodchem.2008.05.111

Malík, F. 2005: Víno Malých Karpát. Bratislava: Albert Marenčin vydavatel'stvo.

Mlček, J., Adámková, A., Škrovánková, S., Adámek, M., Ontrášová, M. (2019). Comparison of antioxidant activity, content of polyphenols and flavonoids in liturgical and common wines. Potravinarstvo Slovak Journal of Food Sciences, 13(1), 218-223. https://doi.org/10.5219/1030

Moreno, J., \& Peinado, R. (2012). Enological Chemistry. Academic Press. https://doi.org/10.1016/c2011-0-69661-9

Mulero, J., Martínez, G., Oliva, J., Cermeño, S., Cayuela, J. M., Zafrilla, P., Barba, A. (2015). Phenolic compounds and antioxidant activity of red wine made from grapes treated with different fungicides. Food Chemistry, 180, 25-31. https://doi.org/10.1016/j.foodchem.2015.01.141

OIV. (2020). World wine production- first estimates. Retrieved from: https://www.oiv.int/public/medias/7541/en-oiv2020-world-wine-production-first-estimates.pdf

Pavloušek, P. (2008). Encyklopedie révy vinné. Computer Press.

Piccardo, D., Favre, G., Pascual, O. (2019) Influence of the use of unripe grapes to reduce ethanol content and $\mathrm{pH}$ on the color, polyphenol and polysaccharide composition of conventional and hot macerated Pinot Noir and Tannat wines. European Food Research and Technology, 245, 13211335. https://doi.org/10.1007/s00217-019-03258-4

Singleton, V. L., \& Rossi, J. A. (1965). Colorimetry of total phenolics with phosphomolybdic-phosphotungstic acid reagents. American Journal of Enology and Viticulture, 16(3), 144-158.

Song, J., Smart, R. E., Dambergs, R. G., Sparrow, A. M., Wells, R. B., Wang, H., Qian, M. C. (2014). Pinot Noir wine composition from different vine vigour zones classified by remote imaging technology. Food Chemistry, 153, 52-59. https:// doi.org/10.1016/j.foodchem.2013.12.037

Sudrand, P. (1958). Interpretation des dabsorption des vins rouges. An. Technology and Agriculture, 7, 203-208.

Šeruga, M., Novak, I., Jakobek, L. (2011). Determination of polyphenols content and antioxidant activity of some red wines by differential pulse voltammetry, HPLC and spectrophotometric methods. Food Chemistry, 124(3), 1208-1216. https://doi.org/10.1016/j.foodchem.2010.07.047

Van Leeuw, R., Kevers, C., Pincemail, J., Defraigne, J. O., Dommes, J. (2014). Antioxidant capacity and phenolic composition of red wines from various grape varieties: Specificity of Pinot Noir. Journal of Food Composition and Analysis, 36(1-2), 40-50. doi:10.1016/j.jfca.2014.07.001

Versari, A., Boulton, R. B., Parpinello, G. P. (2008). A comparison of analytical methods for measuring the color components of red wines. Food Chemistry, 106(1), 397-402. https://doi.org/10.1016/j.foodchem.2007.05.073

Vinohradnícky register SR/ ÚKSUP. (2020). Vinohradnícky register, štatistický prehlad, vinársky rok 2019/2020 Retrieved from: file://C:/Users/admin/Downloads/Vinohradnicky_ register_statistika_vin_rok_2019_2020_web\%20(2).pdf

Welch, C. R., Wu, Q., Simon, J. E. (2008). Recent advances 
in anthocyanin analysis and characterization. Current Analytical Chemistry, 4(2), 75-101. https:/doi. org/10.2174/157341108784587795
Yang, J., Martinson, T. E., Liu, R. H. (2009). Phytochemical profiles and antioxidant activities of wine grapes. Food Chemistry, 116(1), 332-339. https://doi.org/10.1016/j. foodchem.2009.02.021 